\title{
Optimization Modeling of Ethanol Production from Shorgum bicolor Grain: Comparison between Separate Hydrolysis Fermentation and Simultaneous Saccharification Fermentation
}

\author{
RUTH CHRISNASARI*, DAMIATI HARTINI SUSETYO, \\ ADRIAN PRATAMA SUGIANTO, AND TJANDRA PANTJAJANI \\ Department of Biology, Faculty of Biotechnology, Universitas Surabaya, \\ Jalan Raya Kalirungkut, Surabaya 60292, Indonesia
}

\begin{abstract}
Two different process configurations, simultaneous saccharification and fermentation (SSF), and separate hydrolysis and fermentation (SHF), were compared for ethanol production from Shorgum bicolor grain. Optimization modeling for glucoamylase and Zymomonas mobilis concentration in both of SSF and SHF were carried out to obtain optimal concentration of ethanol production. The optimum condition was achieved using $0.021 \%(\mathrm{v} / \mathrm{v})$ of glucoamylase, and $30.19 \%(\mathrm{v} / \mathrm{v})$ of Z. mobilis for SHF. In contrast, the optimum condition for SSF was $0.021 \%(\mathrm{v} / \mathrm{v})$ of glucoamylase and $17.51 \%(\mathrm{v} / \mathrm{v})$ of Z. mobilis. The model predicted SHF processing to be superior. The superiority of SHF over SSF was confirmed experimentally, the result showed ethanol yield of SHF was $134.80 \mathrm{~g} \mathrm{~L}^{-1}$ and ethanol yield of SSF was $115.66 \mathrm{~g} \mathrm{~L}^{-1}$ after $72 \mathrm{~h}$ incubation time. A high similarity was observed between the predicted and experimental results, demonstrating the accuracy of the model.
\end{abstract}

Key words: ethanol, Shorgum bicolor, separate hydrolysis and fermentation, simultaneous saccharification and fermentation

Dua konfigurasi proses yang berbeda, sakarifikasi dan fermentasi simultan (SSF) serta hidrolisis dan fermentasi terpisah (SHF) dibandingkan pada proses produksi etanol dari Shorgum bicolor. Optimasi pemodelan pada konsentrasi glukoamilase dan Zymomonas mobilis dengan konfigurasi SSF dan SHF dilakukan untuk mendapatkan konsentrasi etanol yang optimal. Kondisi optimum dicapai pada konsentrasi glukoamilase $0,021 \%$ (v/v) dan Z. mobilis 30,19\% (v/v) pada kofigurasi SHF. Namun, kondisi optimum untuk SSF dicapai pada glukoamilase $0,021 \%$ (v/v) dan Z. mobilis $17,51 \%$ (v/v). Prediksi model menunjukkan konfigurasi SHF lebih unggul. Keunggulan SHF dibanding SSF telah dikonfirmasi secara eksperimental, hasilnya menunjukkan etanol hasil SHF adalah 134,80 $\mathrm{g} \mathrm{L}^{-1}$, dan etanol hasil SSF adalah $115,66 \mathrm{~g} \mathrm{~L}^{-1}$ setelah 72 jam waktu inkubasi. Kesamaan yang tinggi antara hasil prediksi dan eksperimental menunjukkan keakuratan model.

Kata kunci: etanol, Shorgum bicolor, sakarifikasi dan fermentasi simultan, hidrolisis dan fermentasi terpisah

Because of the recent increase in the gas price and interest in environmental issues, the demand of ethanol as substitute of gasoline has been rapidly increased (Bai et al. 2008). Bioethanol can be produced from many sources of biomass, thus access to raw material is virtually unlimited. The most common raw material is starch and sugar based material because it is easier to convert to ethanol than lignocellulose material (Dumitriu, 1998; Gray et al. 2006). The hydrolysis of starch to monomeric sugars can be achieved in many different ways, including chemical hydrolysis by acid or alkaline and enzymatic hydrolysis. Nowadays, enzymatic hydrolysis is the most widely selected because it gives higher specific product, requires mild reaction conditions, and does not generate side products that inhibit microorganisms.

*Corresponding author; Phone: +6231-2981399, Fax: +6231-2981278, E-mail:ruth_c@staff.ubaya.ac.id
In the last decade, comparison and selection of hydrolysis and fermentation process to obtain higher ethanol yield has gained more interest (Söderström et al. 2005; Ollson et al. 2006; Ohgren et al. 2007; Tu et al. 2009; Drissen et al.2009). There are two configurations for hydrolysis and fermentation processes, namely separate hydrolysis and fermentation (SHF) and simultaneous saccharification and fermentation (SSF). When enzymatic hydrolysis and fermentation are performed sequentially, it is referred to SHF. However, the two process steps are conducted simultaneously, it is referred to SSF.

SSF results in a lower capital cost, reduced risk of contamination and higher ethanol yields than SHF (Wyman et al. 1992; Stenberg et al. 2000). However, when adding biomass solids directly to the bioreactor makes cell recirculation very difficult. In addition, SSF requires compatible fermentation and saccharification reaction conditions, including $\mathrm{pH}$, temperature, and 
optimum substrate concentration (Ballesteros et al. 2004). One problem associated with SSF are the different optimal conditions for saccharification and fermentation, this means that the conditions chosen for SSF are not optimal for both the microorganism and the enzymes. On the other hand, in the SHF process the optimal condition of enzymatic hydrolysis and fermentation can be performed (Gupta et al. 2009). However, SHF leads to high production of sugars, which is problematic if the enzyme is end product inhibited. SSF may thus exhibit lower inhibition of the enzymes because glucose released by enzyme is simultaneously fermented by the microorganism (Prashant et al. 1999).

In the present study, Shorgum bicolor, a grain having high sugar accumulation, was used as raw material for ethanol production. S. bicolor has potential as a raw material for fuel-grade ethanol production due to its rapid growth rate and early maturity, greater water use efficiency, limited fertilizer requirement, high yield production, and wide adoptability (Reddy et al. 2005; Prasad et al. 2007; Antonopoulou et al. 2008). Although SSF and SHF have been investigated extensively, there are still no comparison SSF and SHF modeling to achieve the optimal operating conditions for ethanol production from S. bicolor.

Optimization modeling using Response Surface Methodology (RSM) has been reported to be an efficient method for identifying the effect of individual variables and for seeking the optimum conditions for a multivariable system (Ambati and Ayyanna 2001; Ratnam et al. 2005; Bandaru et al. 2006). This method has superiority compare to other methods due to rapidity, limited number of required experiments, and accuracy for describing the optimal conditions. In this present study, SHF and SSF were compared for ethanol production from $S$. bicolor and optimized by RSM. The RSM approach was adopted to locate optimum level of glucoamylase and Zymomonas mobilis concentration for ethanol production, since these parameters play a key role in the enhancement of ethanol yield (Bandaru et al.2006; Chrisnasari et al.2011).

\section{MATERIALS AND METHODS}

Bacterial Strain. Z. mobilis ZM4 (NRRL B14234) obtained from ARS Culture Collection National Center for Agricultural Utilization Research, Peoria Il, USA, was used throughout the research.

Enzyme. Thermostable alpha amylase (Liquozyme ${ }^{\circledR S C}$ DS, Novozymes) originated from
Bacillus licheniformis and glucoamylase (Dextrozyme ${ }^{\circledR}$ GA, Novozymes) from Aspergillus niger, were employed for starch hydrolysis. The enzymatic activities of these enzymes as defined by Novozymes were 240 KNU-S g ${ }^{-1}$ and $270 \mathrm{AGU} \mathrm{g}^{-1}$, respectively.

Cultivation Medium and Conditions. Z. mobilis was maintained on medium containing $\left(\mathrm{g} \mathrm{L}^{-1}\right)$ : glucose, 100 ; yeast extract, $10 ; \mathrm{KH}_{2} \mathrm{PO}_{4}, 1 ;\left(\mathrm{NH}_{4}\right)_{2} \mathrm{SO}_{4}, 1$; $\mathrm{MgSO}_{4} \cdot 7 \mathrm{H}_{2} \mathrm{O}, 0.5$. Cells were cultured at $35^{\circ} \mathrm{C}$ and $\mathrm{pH}$ of 5.5 with $24 \mathrm{~h}$ incubation time.

Raw Material Pretreatment. Fermentation medium was made by gelatinized S. bicolor flour $(30 \%$ $\mathrm{w} / \mathrm{v}$ ) at $100^{\circ} \mathrm{C}$ for $15 \mathrm{~min}$. Gelatinized slurry maintained under temperature of $85^{\circ} \mathrm{C}$ and $\mathrm{pH}$ of 5.5 , then added with $20 \mu 1 \mathrm{~L}^{-1}$ of alpha amylase and incubated for $2 \mathrm{~h}$ during liquefaction process. The liquefied starch then cooled down and adjusted according to the next step condition.

Separate Hydrolysis and Fermentation. Saccharification was done by keeping the liquefied shorgum starch at $55^{\circ} \mathrm{C}$ and a pH of 4.3 , followed by addition of glucoamylase at vary concentrations and incubated for $48 \mathrm{~h}$. Saccharified starch was adjusted into $\mathrm{pH}$ of 5.5 and centrifuged at $4000 \mathrm{rpm}$ for $15 \mathrm{~min}$. Supernatant was taken for fermentation process. Optimization studies of ethanol production by $Z$. mobilis were carried out in $250 \mathrm{~mL}$ flasks and fermentation conditions were maintained at temperature of $30{ }^{\circ} \mathrm{C}$ and shake of $200 \mathrm{rpm}$ for $72 \mathrm{~h}$. The inoculums was derived from $Z$. mobilis cells that grown overnight which OD at $560 \mathrm{~nm}$ was maintained at 1.5 for both SHF and SSF configuration and for each replication.

Simultaneous Saccharification and Fermentation. The saccharification and fermentation of liquefied starch was carried out simultaneously in one flask. The liquefied medium was added with vary concentration of glucoamylase and inoculated with vary concentration of Z. mobilis suspension, followed by incubation process which maintained at $37^{\circ} \mathrm{C}$ and $200 \mathrm{rpm}$ for 72 h.

Analytical Methods. The concentration of reducing sugars was determined by dinitrosalicylic (DNS) colorimetric assay using glucose as sugar standard (Miller 1959). The concentration of starch was determined according to Halletal.(2000). The amountof ethanol was measured by gas chromatography (Hewlett Packard,HPC1540A). Cell concentration was measured by spectroscopyat $560 \mathrm{~nm}\left(\mathrm{OD}_{560}\right)$.

Experimental Design and Optimization. The aim of this study was to find the optimum levels of glucoamylase and inoculum concentrations for ethanol 
production from S. bicolor. Central composite experimental design RSM (CCD, Box and Wilson, 1951) was used in the optimization of ethanol production. Glucoamylase concentration $\left(X_{1}, \% \mathrm{v} / \mathrm{v}\right)$ and inoculum $\left(X_{2}, \% \mathrm{v} / \mathrm{v}\right)$ were chosen as independent variables and ethanol concentration $\left(Y i, \mathrm{~g} \mathrm{~L}^{-1}\right)$ was used as output variable. For statistical calculations the variables $\mathrm{Xi}$ were coded as $X i$ according to Equation (1).

$$
\mathrm{Xi}=\frac{X i-x i}{\Delta X j} \quad i=1,2,3, \ldots . k
$$

Where, $x_{i}$ is the dimensionless value of an independent variable, $X i$ is the real value of an independent variable, $x i$; is the real value of the independent variable at the center point and $\Delta x j$ is step change. Table 1 shows Independent variable that used in this experimental plan. $\mathrm{A} 2^{2}$-factorial CCD, with four axial points $(\alpha=\sqrt{2})$ and five replications at the center points $\left(n_{0}=5\right)$ leading to a total number of 13 experiments was employed in Table 1 and 2 .

The second degree polynomials (Equation (2)) were calculated with the statistical package (Stat-Ease Inc, Minneapolis, MN, USA) to estimate the response of the dependent variable:

$$
Y i=b_{0}+b_{1} X_{1}+b_{2} X_{2}+b_{11} X_{1}^{2}+b_{22} X_{2}^{2}+b_{12} X_{1} X_{2}+
$$

where $Y i$ is the predicted response, $X_{1}, X_{2}$, are independent variables, $b_{0}$, is the offset term, $b_{1}, b_{2}$, are linear effects, $b_{11}, b_{22}$ are squared effects and $b_{12}$ is interaction terms.

\section{RESULTS}

The two factors that most influence the enzymatic starch hydrolysis and fermentative production of ethanol are glucoamylase concentration and inoculum concentration. RSM was applied to find the optimal condition for each of these. The vicinity of the optimum condition for ethanol production was estimated through steepest ascent step at the preliminary study by varying concentrations of glucoamylase and Z. mobilis inoculum in both SHF and SSF configuration. The glucoamylase concentration was varied from $0.005-0.04 \%(\mathrm{v} / \mathrm{v})$ and the inoculum was varied from $10-40 \%(\mathrm{v} / \mathrm{v})$. The three points closest to the optimum range were used as selected values for the RSM experiment. The preliminary results showed that each fermentation configuration (SHF and SSF) led to a different optimal range for glucoamylase and inoculum concentrations. Both of SHF and SSF showed optimal sugar concentration at $0.02 \%(\mathrm{v} / \mathrm{v})$ of glucoamylase concentration (Fig 1A) therefore the optimum range of glucoamylase for SHF was $0.015-0.025 \%(\mathrm{v} / \mathrm{v})$. In other hand, there was insignificant difference of sugar concentration between 0.02 and $0,025 \%(\mathrm{v} / \mathrm{v})$ of glucoamylase concentration in SSF configuration, consequently the optimal range was expanded to $0.010-0.030 \%(\mathrm{v} / \mathrm{v})$. In contrast, the optimal inoculums range for SHF configuration was 25-35\% (v/v) and for SSF configuration was 10-25\% (v/v) (Fig 1B). These points then were used as the lower factorial point ( -1 of coded factor), center point ( 0 of coded factor), and upper factorial point (1 of coded factor) in CCD matrix design as listed in Table 1.

Using CCD, a total number of 13 experiments with different combinations of glucoamylase and inoculum were performed (Table 2). The response was taken at the maximum ethanol production which was observed at $72 \mathrm{~h}$ incubation time. The estimation model analysis was done using Sequential Model Sum of Squares, Lack of Fit Tests and Model Summary Statistics. The result showed that suggestion model was quadratic which means relationship between variables and response followed a quadratic function. The following second order polynomial equation was found to represent the ethanol production adequately for SHF and SSF configuration:

Equation for SHF configuration:

$$
\begin{aligned}
\mathrm{y}= & -39.30774+6029.10590 X_{1}+7.54986 X_{2}+6.99500 \\
& X_{1} X_{2}-1.52150 \mathrm{E}+005 X_{1}^{2}-0.12739 X_{2}^{2}
\end{aligned}
$$

Equation for SSF configuration:

$$
\begin{aligned}
\mathrm{y}= & -89.32138+9446.26618 X_{1}+11.83360 X_{2}+21.04800 \\
& X_{1} X_{2}-2.30690 \mathrm{E}+005 X_{1}^{2}-0.35069 X_{2}^{2}
\end{aligned}
$$

The experimental data as shown at Table 2 were statistically analyzed using the Fischer's statistical test for analysis of variance (ANOVA) and the results are shown in Table 3. The ANOVA of the quadratic regression model indicated that the model for SHF and SSF were highly significant where the Prob $>F$-value of the model was less than 0.0500 . The coefficient estimate and the corresponding Prob $>$ F-values demonstrated that glucoamylase concentration had a significant effect on ethanol production in SHF configuration but not in SSF configuration. However, inoculum concentrations were observed to have an insignificant effect on ethanol production in both SSF and SHF configuration. The analysis also showed that there were insignificant interactions between glucoamylase and inoculums concentration for both 

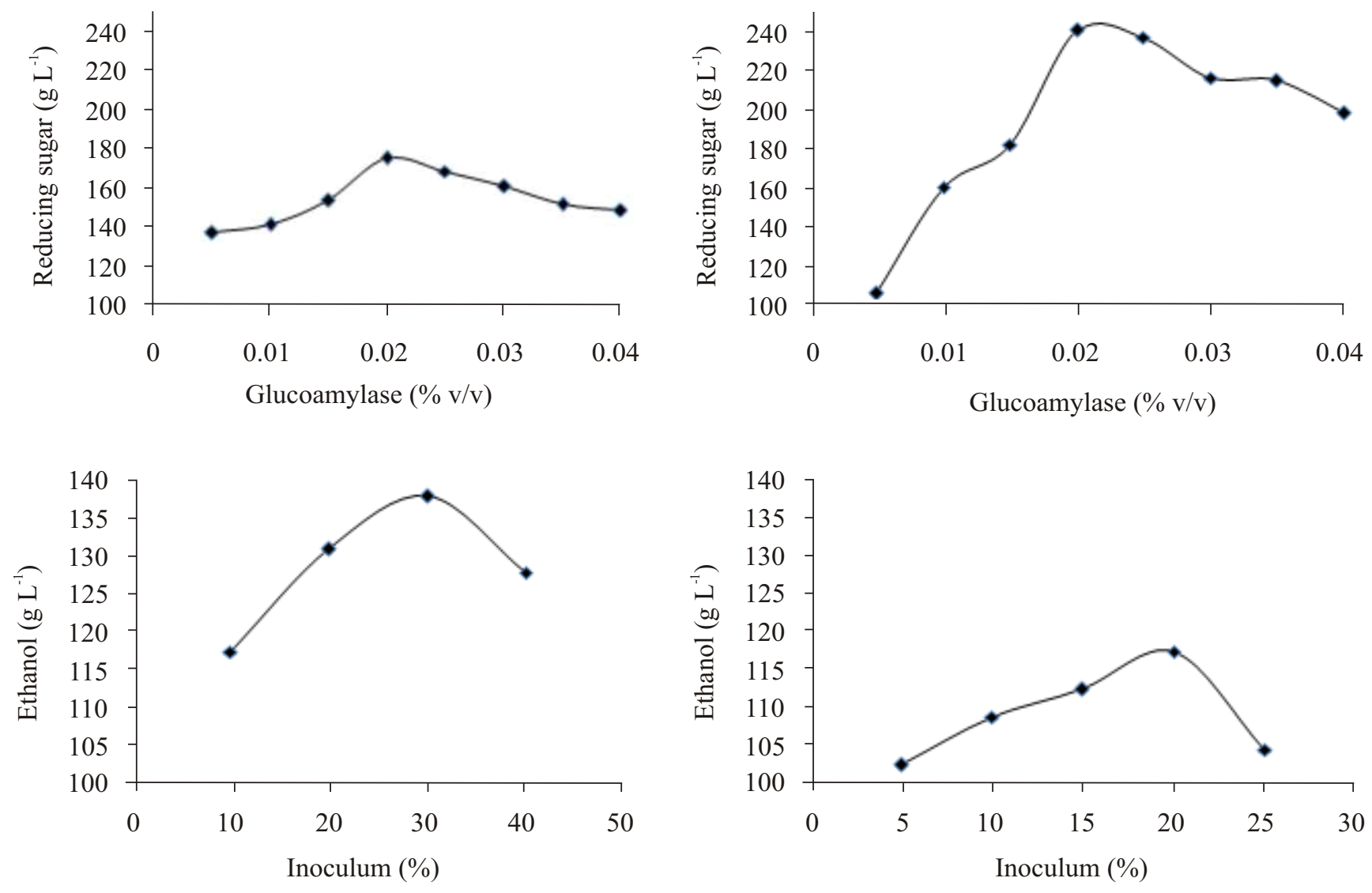

A

B

Fig 1 The effect of glucoamylases concentration to the amount of sugar released and the effect of inoculum concentration to the amount of ethanol produced at $72 \mathrm{~h}$ incubation time in (A) SHF configuration, (B) SSF configuration.

SSF and SHF. In addition, there were significant effects of quadratic function for SSF and SHF configuration respectively.

The coefficient determination of SHF configuration, $\mathrm{R}^{2}$ is 0.9785 and for SSF configuration, $\mathrm{R}^{2}$ is 0.9278 which implies that most of the sample variation in the ethanol yield was attributed to the independent variables. Adequate precision measures the signal to noise ratio. Adequate precision ratio of 18.228 for SHF configuration and 9.837 for SSF configuration indicate an adequate signal, so that these models can be used to navigate the design space.

The predicted optimum levels glucoamylase and inoculums were obtained by applying the regression analysis to the Equation (3) and (4). The predicted and experimental ethanol production at the optimum levels of glucoamylase and inoculums also determined by using Equation (3) and (4). Fig 2 represent the response

Table 1 Independent variable in the experimental plan

\begin{tabular}{|c|c|c|c|c|c|}
\hline \multirow{2}{*}{ Variable } & \multicolumn{5}{|c|}{ Actual value of each coded level } \\
\hline & -1.414 & -1 & 0 & 1 & 1.414 \\
\hline \multicolumn{6}{|l|}{ SHF: } \\
\hline $\begin{array}{ll}\text { - } & \text { Glucoamylase } \\
\text { concentrations }(\% \mathrm{v} / \mathrm{v}), X_{I}\end{array}$ & 0.0129 & 0.015 & 0.020 & 0.025 & 0.0271 \\
\hline $\begin{array}{l}\text { Inoculum concentration } \\
(\% \mathrm{v} / \mathrm{v}), X_{2}\end{array}$ & 22.9 & 25.0 & 30.0 & 35.0 & 37.1 \\
\hline \multicolumn{6}{|l|}{ SSF: } \\
\hline $\begin{array}{ll}\text { - } & \text { Glucoamylase } \\
\text { concentrations }(\% \mathrm{v} / \mathrm{v}), X_{I}\end{array}$ & 0.0059 & 0.010 & 0.020 & 0.030 & 0.0341 \\
\hline $\begin{array}{l}\text { Inoculum concentration } \\
(\% \mathrm{v} / \mathrm{v}), X_{2}\end{array}$ & 6.9 & 10.0 & 17.5 & 25.0 & 28.1 \\
\hline
\end{tabular}


Table 2 Experimental and the predicted value of ethanol yield

\begin{tabular}{|c|c|c|c|c|c|c|c|}
\hline \multicolumn{4}{|c|}{ SHF } & \multicolumn{4}{|c|}{ SSF } \\
\hline $\begin{array}{c}\text { Glucoamylase } \\
(\% \mathrm{v} / \mathrm{v})\end{array}$ & $\begin{array}{l}\text { Inoculum } \\
(\% \mathrm{v} / \mathrm{v})\end{array}$ & $\begin{array}{l}\text { Actual ethanol } \\
\qquad\left(\mathrm{g} \mathrm{L}^{-1}\right)\end{array}$ & $\begin{array}{l}\text { Predicted } \\
\text { ethanol }\left(\mathrm{g} \mathrm{L}^{-1}\right)\end{array}$ & $\begin{array}{c}\text { Glucoamylase } \\
(\% \mathrm{v} / \mathrm{v})\end{array}$ & $\begin{array}{c}\text { Inoculum } \\
(\% \mathrm{v} / \mathrm{v})\end{array}$ & $\begin{array}{l}\text { Actual ethanol } \\
\qquad\left(\mathrm{g} \mathrm{L}^{-1}\right)\end{array}$ & $\begin{array}{c}\text { Predicted } \\
\text { ethanol }\left(\mathrm{g} \mathrm{L}^{-1}\right)\end{array}$ \\
\hline 0.015 & 25.0 & 129.38 & 128.65 & 0.010 & 10.0 & 67.82 & 67.44 \\
\hline 0.025 & 25.0 & 130.31 & 129.83 & 0.030 & 10.0 & 77.51 & 76.03 \\
\hline 0.015 & 35.0 & 128.73 & 128.76 & 0.010 & 25.0 & 58.37 & 63.99 \\
\hline 0.025 & 35.0 & 130.36 & 130.64 & 0.030 & 25.0 & 74.38 & 78.89 \\
\hline 0.020 & 30.0 & 135.86 & 136.46 & 0.020 & 17.5 & 116.65 & 114.38 \\
\hline 0.020 & 30.0 & 135.77 & 136.46 & 0.020 & 17.5 & 100.58 & 114.38 \\
\hline 0.020 & 30.0 & 136.60 & 136.46 & 0.020 & 17.5 & 120.78 & 114.38 \\
\hline 0.020 & 30.0 & 137.38 & 136.46 & 0.020 & 17.5 & 109.66 & 114.38 \\
\hline 0.020 & 30.0 & 136.69 & 136.46 & 0.020 & 17.5 & 124.24 & 114.38 \\
\hline 0.0129 & 30.0 & 127.37 & 127.77 & 0.0059 & 17.5 & 62.80 & 59.94 \\
\hline 0.0271 & 30.0 & 129.88 & 129.93 & 0.0341 & 17.5 & 77.83 & 76.55 \\
\hline 0.020 & 22.9 & 128.99 & 129.76 & 0.020 & 6.9 & 72.97 & 75.14 \\
\hline 0.020 & 37.1 & 130.73 & 130.42 & 0.020 & 28.1 & 81.03 & 74.72 \\
\hline
\end{tabular}

Table 3 Analysis of variance (ANOVA) for the response surface quadratic model

\begin{tabular}{|c|c|c|c|c|c|c|c|c|c|c|}
\hline \multirow[b]{2}{*}{ Source } & \multicolumn{5}{|c|}{ SHF } & \multicolumn{5}{|c|}{ SSF } \\
\hline & $\begin{array}{l}\text { Sum of } \\
\text { square }\end{array}$ & $\mathrm{df}$ & $\begin{array}{l}\text { Mean } \\
\text { square }\end{array}$ & F-value & $\begin{array}{l}\mathrm{p} \text {-value } \\
\text { prob }>\mathrm{F}\end{array}$ & $\begin{array}{l}\text { Sum of } \\
\text { square }\end{array}$ & df & $\begin{array}{l}\text { Mean } \\
\text { square }\end{array}$ & F-value & $\begin{array}{l}\text { p-value } \\
\text { prob }>F\end{array}$ \\
\hline Model & 157.04 & 5 & 31.41 & 63.79 & $<0.0001$ & 5965.76 & 5 & 1193.15 & 17.98 & 0.0007 \\
\hline$X_{1}$ & 4.68 & 1 & 4.68 & 9.51 & 0.0177 & 275.67 & 1 & 275.67 & 4.15 & 0.0809 \\
\hline$X_{2}$ & 0.43 & 1 & 0.43 & 0.88 & 0.3799 & 0.18 & 1 & 0.18 & 0.00265 & 0.9604 \\
\hline$X_{1} X_{2}$ & 0.12 & 1 & 0.12 & 0.25 & 0.6334 & 9.97 & 1 & 9.97 & 0.15 & 0.7099 \\
\hline$X_{1}^{2}$ & 100.65 & 1 & 100.65 & 204.43 & $<0.0001$ & 3702.11 & 1 & 3702.11 & 55.78 & 0.0001 \\
\hline$X_{2}^{2}$ & 70.55 & 1 & 170.55 & 143.30 & $<0.0001$ & 2707.05 & 1 & 2707.05 & 40.78 & 0.0004 \\
\hline Residual & 3.45 & 7 & 0.49 & & & 464.56 & 7 & 66.37 & & \\
\hline Lack of fit & 1.70 & 3 & 0.57 & 1.29 & 0.3916 & 108.53 & 3 & 36.18 & 0.41 & 0.7573 \\
\hline Pure error & 1.75 & 4 & 0.44 & & & 356.03 & 4 & 89.01 & & \\
\hline Corrected & 160.49 & 12 & & & & 6430.32 & 12 & & & \\
\hline Total & & & & & & & & & & \\
\hline
\end{tabular}

Table 4 The predicted and experimental ethanol yield at the optimum levels of glucoamylase and inoculums

Variables

\begin{tabular}{lccc}
\multicolumn{1}{c}{ Variables } & Optimum level & Optimum ethanol yield $\left(\mathrm{g} \mathrm{L}^{-1}\right)$ \\
SHF: & & Experimental & Predicted \\
\hline - $\quad$ Glucoamylase concentrations $(\% \mathrm{v} / \mathrm{v}), X_{1}$ & 0.021 & 134.80 & 136.50 \\
- $\quad$ Inoculum concentration $(\% \mathrm{v} / \mathrm{v}), X_{2}$ & 30.19 & \\
SSF: & & 115.66 \\
- Glucoamylase concentrations $(\% \mathrm{v} / \mathrm{v}), X_{1}$ & 0.021 & 114.76 \\
- Inoculum concentration $(\% \mathrm{v} / \mathrm{v}), X_{2}$ & 17.51 & & \\
\hline
\end{tabular}



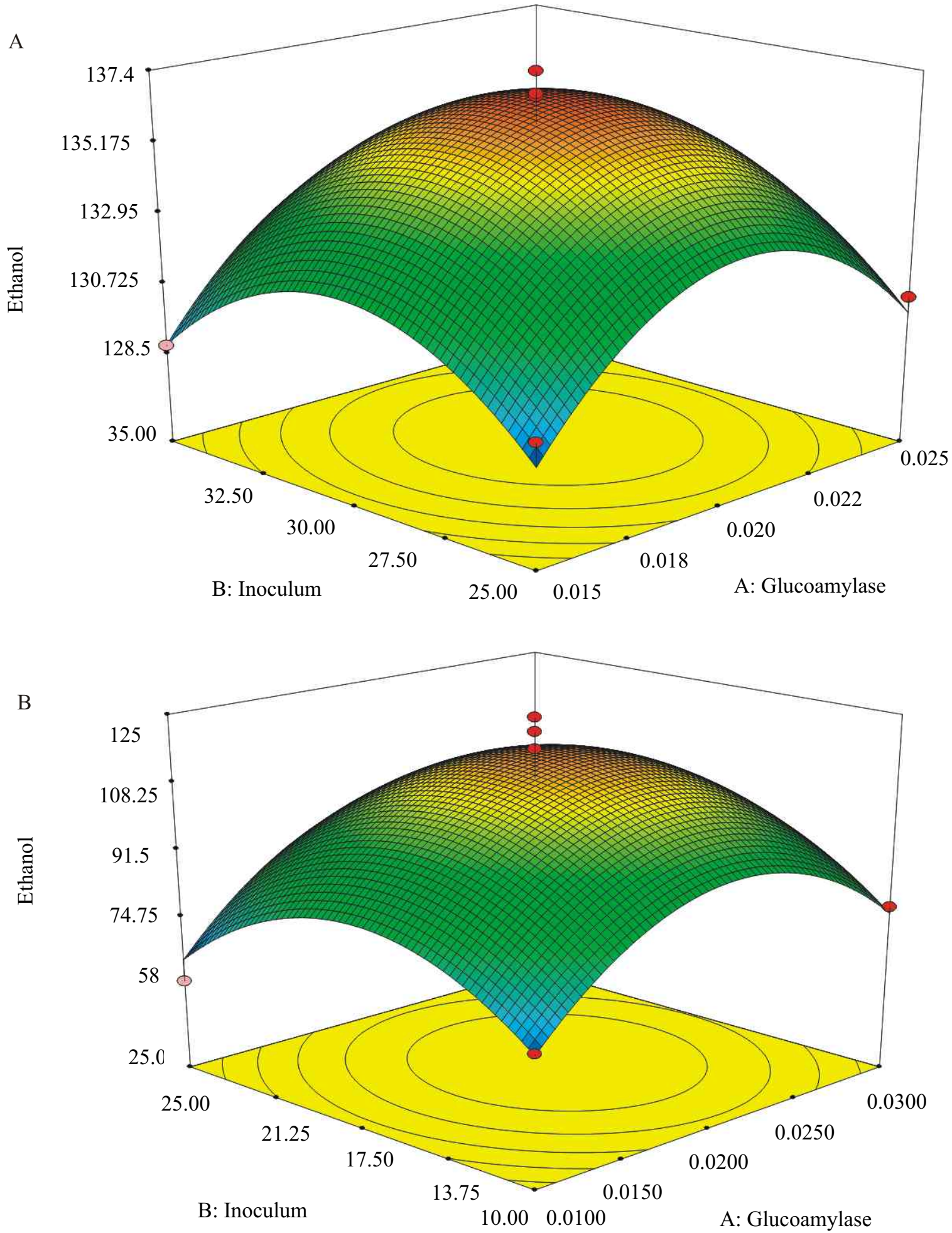

Fig 2 Response surface and contour plot of glucoamylase vs. inoculums on ethanol production: (A) SHF configuration, (B) SSF configuration.

surface and contour plots for the optimization of inoculums vs. glucoamylase on ethanol production. The optimum condition of SHF configuration for highest ethanol production can be achieved at the glucoamylase concentration of $0.021 \%(\mathrm{v} / \mathrm{v})$ and 30.19 $\%(\mathrm{v} / \mathrm{v})$ of inoculums. At these optimum conditions maximum ethanol production of $136.50 \mathrm{~g} \mathrm{~L}^{-1}$ was predicted.

In other hand, the optimum condition for SSF configuration can be achieved at the glucoamylase concentration of $0.021 \%(\mathrm{v} / \mathrm{v})$ and inoculum concentration of $17.51 \%(\mathrm{v} / \mathrm{v})$ which gives the maximum ethanol production of $114.76 \mathrm{~g} \mathrm{~L}^{-1}$. Either experimental or predicted ethanol production at the 
optimum condition for SHF and SSF configuration were also determined (Table 4). The modeling result predicted SHF processing to be superior to SSF. The superiority of SHF over SSF was confirmed experimentally, the result showed ethanol yield of SHF was $134.80 \mathrm{~g} \mathrm{~L}^{-1}$ and ethanol yield of SSF was $115.66 \mathrm{~g}$ $\mathrm{L}^{-1}$ after $72 \mathrm{~h}$ incubation time.

\section{DISCUSSIONS}

In the present study, we demonstrated the production of high ethanol concentrations from S. bicolor using the SHF and SSF configurations. The results demonstrated that glucoamylase and inoculum concentrations influenced to the enzymatic starch hydrolysis and fermentative production of ethanol. Increasing glucoamylase concentration positively influenced ethanol production in SHF configuration, as the liquefied starch in sorghum gets converted to glucose in the presence of glucoamylase enzyme. The increasing of glucoamylase concentration has lead to increasing of rate conversion of liquefied starch to glucose which resulted increasing of glucose concentration in medium. As in SHF hydrolysis and fermentation are separate, the best reaction conditions for each can be independently selected (Gupta et al. 2009; Ohgren et al. 2007). However, for SSF one set of conditions has to be selected. This usually means selecting a lower than optimal temperature for the enzyme to accommodate the microorganism (Anuradha et al. 1999). This problem recommends the superiority of ethanol production of SHF over than SSF configuration.

Previous investigation on ethanol production had to compare the SSF and SHF configuration at the same reaction condition in order to be able to compare the performance for both systems (Zhang et al. 2011). The previous result showed that SSF was superior to SHF due to the comparison was done at the same reaction condition. In this study, SHF and SSF were optimized before comparing ethanol yields for SHF and SSF. Optimal conditions were determined using RSM for both experimental efficiency and accuracy which may lead to the different reaction conditions for each system. At their each optimum condition, SHF was found to be superior to SSF on the basis of final ethanol yield.

\section{REFERENCES}

Ambati P, Ayyanna C. 2001. Optimizing medium constituents and fermentation conditions for citric acid production from palmyra jaggery using response surface method. World J Microbiol Biotechnol. 17(4): 331-335. doi:10.1023/A:1016613322396.

Antonopoulou G, Gavala HN, Skiadas IV, Angelopoulos K, Lyberatos G. 2008. Biofuels generation from sweet sorghum: Fermentative hydrogen production and anaerobic digestion of the remaining biomass. Bioresour Technol. 99(1):110-119. doi:10.1016/j.biortech.2006.11.048.

Anuradha R, Suresh AK, Venkatesh KV. 1999. Simultaneous saccharification and fermentation of starch to lactic acid. Process Biochem. 35(3-4):367-375. doi:10.1016/S00329592(99)00080-1.

Bai FW, Anderson WA, Young MM. 2008. Ethanol fermentation technologies from sugar and starch feedstock. Biotechnol Adv. 26(1):89-105. doi:10.1016/S0032-9592(99)00080-1.

Ballesteros M, Oliva JM, Negro MJ, Manzanares P, Ballesteros I. 2004. Ethanol from lignocellulosic materials by a simultaneous saccharification and fermentation process (SSF) with Kluyveromyces marxianus CECT 10875. Process Biochem. 39(12):1843-1848. doi:10.1016/j.procbio.2003.09.011.

Bandaru VVR, Somalanka SR, Mendu DR, Madicherla NR, Chityala A. 2006. Optimization of fermentation conditions for the production of ethanol from sago starch by co-immobilized amyloglucosidase and cells of Zymomonas mobilis using response surface methodology. Enzyme Microbiol Technol. 38(12):209-214. doi:10.1016/j.enzmictec.2005.06.002.

Box GEP, Wilson KB. 195. On the experimental attainment of optimum conditions. J R Stat Soc Series B Stat Methodol. 13(1):1-45.

Box GEP, Hunter JS, HunterWG. 2005. Statistic for experimenters: design, innovation and discovery. New Jersey: JohnWilley \& Sons. p 450-453.

Chrisnasari R, Wardani AK, Murdiyatmo U. 2011. Optimization of ethanol production from palmyra sap by Zymomonas mobilis using response surface method Microbiol Indones. 5(2):61-67. doi:10.5454/mi.5.2.3.

Drissen RET, Maas RHW, Tramper J, Beeftink HH. 2009. Modelling ethanol production from cellulose: separate hydrolysis and fermentation versus simultaneous saccharification and fermentation. Biocatal Biotransfor. 27(1):27-35. doi:10.1080/10242420802564358.

Dumitriu S. 1998. Polysaccharides. New York: Markker Deccer Inc.

Gray KA, Zhao L, Emptage M. 2006. Bioethanol. Curr Opin Chem Biol. 10(2):141-146. doi:10.1016/j.cbpa.2006.02.035.

Gupta R, Sharma KK, Kuhad RC. 2009. Separate hydrolysis and fermentation (SHF) of Prosopis juliflora, a woody substrate, for the production of cellulosic ethanol by Saccharomyces cerevisiae and Pichia stipitis-NCIM 3498. Bioresour Technol. 100(3):1214-1220. doi:10.1016/j.biortech.2008.08.033.

Hall MB, Ennings JP, Lewis JBA, Robertson JB. 2000. Evaluation of starch analysis methods for feed samples. J Sci Food Agric. 81(1):17-21. doi:10.1002/10970010(20010101)81:1<17::AID-JSFA758>3.0.CO;2-B. 
Miller GL. 1959. Use of DNS reagent for determination of reducing sugars. Anal Chem. 31(3):426-428. doi:10.1021/ac60147a030.

Ohgren K, Bura R, Lesnicki G, Saddler J, Zacchi G. 2007. A comparison between simultaneous saccharification and fermentation and separate hydrolysis and fermentation using steam-pretreated corn stover. Process Biochem. 42(5):834-839. doi:10.1016/j.procbio.2007.02.003.

Olsson L, Soerensen HR, Dam BP, Christensen H, Krogh KM, Meyer AS. 2006. Separate and simultaneous enzymatic hydrolysis and fermentation of wheat hemicellulose with recombinant xylose utilizing Saccharomyces cerevisiae. Appl Biochem Biotech. 129 (1-3):117-129. doi:10.1385/ABAB:129:1:117.

Prasad S, Singh A, Jain N, Joshi HC. 2007. Ethanol production from sweet sorghum syrup for utilization as automotive fuel in india. Energy Fuel 21(4):2415-2420. doi:10.1021/ef060328z.

Prashant V, Iyer, Lee YY. 1999. Simultaneous saccharification and extractive fermentation of lignocellulosic materials into lactic acid in a two-zone fermentor-extractor system. Appl Biochem Biotechnol. 77(79):409-418.

Ratnam BVV, Rao SS, Rao DM, Rao NM, Ayyanna C. 2005. Optimization of medium constituents and fermentation conditions for the production of ethanol from palmyra jaggery using response surface methodology. World J Microbiol Biotechnol. 21(4):399-404. doi:10.1007/s11274004-2461-4.

Reddy BVS, Ramesh S, Reddy PS, Ramaiah B, Salimath PM, Kachapur R. 2005. Sweet sorghum-a potential alternate raw material for bio-ethanol and bioenergy. ICRISAT 1(1):1-8.

Söderström J, Galbe M, Zacchi G. 2005. Separate versus simultaneous saccharification and fermentation of two step steam pretreated softwood for ethanol production. J Wood Chem Technol. 25(3):187-202. doi:10.1080/02773810500191807.

Stenberg K, Bollok M, Reczey K, Galbe M, Zacchi G. 2000. Effect of substrate and cellulase concentration on simultaneous saccharification and fermentation of steampretreated softwood for ethanol production. Biotechnol Bioeng. 68(2):204-210. doi:10.1002/(SICI)10970290(20000420)68:2<204::AID-BIT9>3.0.CO;2-4.

Tu M, Zhang X, Paice M, McFarlane P, Saddler JN. 2009. Effect of surfactants on separate hydrolysis fermentation and simultaneous saccharification fermentation of pretreated lodgepole pine. Biotechnol Progr. 25(4):1122-1129. doi:10.1002/btpr.198.

Wyman CE, Spindler DD, Grohmann K. 1992. Simultaneous saccharification and fermentation of several lignocellulosic feedstocks to fuel ethanol. Biomass Bioenerg. 3(5):301-307. doi:10.1016/09619534(92)90001-7.

Zang L, Zhao H, Gan M, Jin Y, Gao X, Chen Q, Guan J, Wang Z. 2011. Application of simultaneous saccharification and fermentation (SSF) from viscosity reducing of raw sweet potato for bioethanol production at laboratory, pilot and industrial scales. Bioresour Technol. 102(6): 4573-4579. doi:10.1016/j.biortech.2010.12.115. 